\title{
Psikolojik Sermaye İle İş Tatmini Arasındaki İlişki: Sağlık Çalışanlarında Bir Uygulama ${ }^{1}$
}

\author{
Mustafa MACIT \\ Dr. Öğr. Üyesi, Kahramanmaraş Sütçü İmam Üniversitesi, \\ İktisadi ve İdari Bilimler Fakültesi, Sağlık Yönetimi Bölümü \\ mustafamacit@ksu.edu.tr \\ Orcid ID: https://orcid.org/0000-0002-5672-5161
}

\section{Mesut KARAMAN}

Uzman, mesut_karaman66@hotmail.com

Orcid ID: https://orcid.org/0000-0001-6154-8940

\section{Mehmet Akif CERAN}

Uzman, makif.crn.409@hotmail.com

Orcid ID: https://orcid.org/0000-0001-6052-6395

\section{Öz}

Bu çalışma hizmet sektörünün önemli bir parçası olan sağlık çalışanlarında psikolojik sermaye ile iş tatmini arasındaki ilişkiyi belirlemek ve sağlık çalışanlarının psikolojik sermaye düzeylerini tespit etmek amacıyla yapılmıştır. Araştırma bir devlet hastanesinde 180 sağlık çalışanından elde edilen veriler doğrultusunda gerçekleștirilmiștir. Veri toplama araçları olarak Luthans vd., (2007) tarafindan geliştirilen, Çetin ve Basım (2012) tarafından Türkçe'ye uyarlama çalışması yapılan Psikolojik Sermaye Ölçeği ile Hackman ve Oldman (1975) İş Özellikleri anketinden Türkçe'ye uyarlama çalışması Basım ve Şeşen (2009) tarafından yapılmış olan, İş Tatmini Ölçeği kullanılmıştır. Verilerin analiz edilmesinde sayı-yüzdelik hesaplama, frekans, t testi, tek yönlü varyans analizi ve Pearson korelasyon analiz yöntemleri uygulanmıştır. Bu çalışma da psikolojik sermaye ile iş tatmini arasında pozitif yönlü anlamlı düzeyde bir ilişki olduğu belirlenmiştir. Katılımcıların psikolojik sermaye puan ortalamaları literatür ile

\footnotetext{
${ }^{1}$ Makale Geliş/Kabul Tarihi: 08.05.2019 / 02.04.2020

Künye Bilgisi: Macit, M., Karaman, M. ve Ceran, M.A. (2020). Psikolojik Sermaye İle İş Tatmini Arasındaki İlişki: Sağlık Çalışanlarında Bir Uygulama. Kahramanmaraş Sütçü Imam Üniversitesi Sosyal Bilimler Dergisi, 17 (1), 380-404. DOI: 10.33437/ksusbd.561842
} 
karşılaştırıldığında yüksek seviyede bulunmuştur. Ayrıca demografik değişkenlerden cinsiyet, yaş, bulundukları kurumda çalışma süresi ve toplam mesleki yıl ile psikolojik sermaye düzeyleri arasında istatistiksel olarak anlamlı bir farklılık olduğu saptanmıştır.

Anahtar Kelimeler: Sağlık Çalışanları, Psikolojik Sermaye, İş Tatmini.

\title{
The Relationship Between Psychological Capital And Job Satisfaction: An Application In Health Employees
}

\begin{abstract}
This study was conducted to determine the relationship between psychological capital and job satisfaction in health workers, which is an important part of the service sector, and to determine psychological capital levels of health workers. The study was carried out in the direction of the data obtained from 180 health workers working in a State Hospital. Scales used as data collection tools are the Psychological Capital Scale developed by Luthans et al. (2007), adapted into Turkish by Çetin ve Basım (2012) and Hackman and Oldman's (1975) Work Characteristics Questionnaire Job Satisfaction Scale was adapted by Basim and Şeşen (2009). In the analysis of the data, number-percentage calculation, frequency, $t$ test, one way and variance analysis and pearson correlation analysis methods were applied. According to the study there is a positively statistically meaningful relationship between psychological capital and job satisfaction levels. Participants' psychological capital score averages were found higher when compared with the literature. In addition to that, the relations between psychological capital levels and demographic variables, gender, age, duration of woking time in institution and total vocational year, were found to be statistically significant $(\mathrm{p}<0,05)$.
\end{abstract}

Keywords: Health Workers, Psychological Capital, Job Satisfaction.

\section{GİRIŞ}

Günümüzde rekabetin kaçınılmaz olması, gelişen teknoloji ve değişim karşısında işletmelerin uyum sağlama zorunluluğu, sürekli daha iyinin istenmesi, çevresel firsat ve tehditlerin etkileri ve amaçlanan stratejik hedeflere ulaşmanın gerekliliği işletmeleri yoğun bir çalışma ortamı içerisine çekmektedir. Çalışanların yoğun iş temposu içinde olması üzerlerindeki baskıyı arttırmakta, psikolojik olarak etkilenmelerine ve yaptıkları işlerde hedefledikleri tatmin 
düzeyine ulaşmalarında zorluklara sebep olabilmektedir. Bu durum çalışanlar üzerinde verim düşüklüğü, performans kaybı, iş hayatı ve sosyal yaşamda aksamalara yol açmakta ve bireyler ve kurumlar bundan olumsuz olarak etkilenebilmektedirler.

İşletmelerin rekabet üstünlüğü sağlaması, çalışanların hem iş hayatında hem de sosyal hayatında mutlu ve başarılı olması, bireylerin kurumları açısından yaşadıkları olumsuz durumların üstesinden gelebilmek, olumlu yönlerini daha iyi nasıl ortaya koyabileceklerini belirlemek adına pozitif örgütsel davranış alanında çok sayıda çalışma yapılmaktadır. Bu bağlamda bireylerin olumlu yönlerini araştıran ve verimliliğini yükseltmeye çalışan psikolojik sermaye de üzerinde araştırmaların arttığı önemli konuların başında gelmektedir.

Pozitif örgütsel davranışın içerisinde değerlendirebilecek psikolojik sermaye Luthans vd. (2006: 3) tarafından yapılan tanıma göre bireyin pozitif psikolojik gelişme durumu olarak ifade edilmektedir. Örgütlerin rekabet üstünlüğü sağlayan diğer sermaye türlerine (insan, sosyal ve ekonomik sermaye) ilave olarak ortaya çıkan psikolojik sermaye, bireyin kim olduğu ve gelişimsel anlamda kim olabileceği ile ilgilenmektedir. Psikolojik sermaye bugünün örgütlerinde insan sermayesini daha iyi anlamak ve ondan daha çok fayda sağlanması için daha anlaşılır bir kavramsal çerçeve ortaya koymaktadır (Kutanis ve Oruç, 2014: 150). Günümüz iş dünyasında rekabet ortamının giderek zorlaşmasıyla ve insan kaynağına dayalı bir iş hakimiyetinin ortaya çıkmasıyla çalışanın verimliliği ve örgüte olan katkıları her geçen gün daha fazla önem arz etmektedir. Bu bağlamda pozitif örgütsel davranışın bir dalı olan psikolojik sermaye çalışanların verimlilik ve performans artışında bireysel gelişime daha çok dikkat çekmektedir (Erkuş ve Findikl1, 2013: 303).

Psikolojik sermaye ile ilgili yapılan araştırmalarda psikolojik sermaye düzeyinin yüksekliğinin çalışanların iş tatmini, bağlllık, yenilikçilik, kariyer, liderlik, yaratıc1lık, katılımcılık, karar yetkinliği, öğrenme becerisi ve girişimciliklerini (Luthans vd., 2006: 42) olumlu etkilediği araştırmaların ortaya çıkardığı bir sonuçtur. Bu bağlamda psikolojik sermaye kurumların başarıya ulaşmasında önemli katkılar sağlayabilecek bir olgu olarak değerlendirilebilir.

Pozitif örgütsel davranış alanında örgütsel açıdan istenilen sonuçlardan birisi de çalışanların psikolojik sermaye düzeyleri ile iş tatmini düzeylerinin yüksek olmasıdır. Günümüz işletmelerinin performanslarını arttırabilmeleri için çalışanların psikolojik sermaye düzeylerini ölçmek, etkin bir şekilde yönetmek ve geliştirilmesini sağlamak büyük bir önem taşımaktadır. Çalışanların işin özellikleri ile ilgili yaptıkları değerlendirmeler sonucunda olumlu duygulara sahip olması olarak tanımlanan iş tatmini kavramı ise işletmenin performansı ile doğrudan ilgilidir. İş tatmini yüksek olan çalışanların iş tatmini daha düşük olan 
çalışanlara göre, daha verimli ve performans seviyeleri de daha yüksek olmaktadır (Robbins ve Judge, 2012; 81-85; Kökalan ve Şevik, 2017: 714).

Bu araştırmanın amacı Türkiye genelinde az sayıda çalışma bulunan sağlık çalışanlarının psikolojik sermaye düzeyleri ile iş tatmini arasındaki ilişkiyi belirlemektir Ayrıca çalışmada sağlık çalışanlarının psikolojik sermaye düzeyleri araştırılmış ve demografik değişkenler açısından da bir farklılık olup olmadığ da incelenmiştir.

\section{KAVRAMSAL ÇERÇEVE}

\section{Psikolojik Sermaye}

İş hayatında, çalışanların davranışlarının olumsuz yönüne odaklanılması, ortaya çıkan her sonucun negatif yönünün vurgulanması ve bu sonuçların iş hayatındaki aksamaların nedeni olarak algılanması, işgörenlerin de işyerlerindeki görevlerini yapması sırasında karşı karşıya kaldıkları kişisel ve işe yönelik olan sorunlara karşı çözüm bulamaması olayları daha karmaşı hale getirmektedir. Çalışanların performanslarında olumsuzluklar yaşansa dahi işgörenlerin de olumlu yönelimleri olduğu, değişime ve gelişime açık oldukları, performans değerlendiricileri tarafindan muhakkak dikkate alınmalıdır. Tam bu noktada işgörenlerin olumlu yönlerini ortaya koyan ve daha ileri düzeye taşımayı hedefleyen psikolojik sermaye kavramı gündeme gelmektedir (Erkmen ve Esen 2012: 56).

İlk defa Maslow tarafindan gündeme getirilen pozitif psikoloji hem psikoloji hem de örgütsel davranış alanında önem kazanan bir olgu olarak dikkat çekmektedir (Wright, 2003: 437). Pozitif psikolojinin amac1, psikolojinin odak noktasında bir değişim olarak, sadece hayattaki kötü şeyleri tamir etmeye odaklanmak değil, aynı zamanda pozitif nitelikler bina etmek üzerine hareket etmektedir (Seligman ve Csikszentmihalyi, 2000: 5). Pozitif psikolojinin örgütsel davranış alanına yansımalarının başında pozitif psikolojik sermaye gelmektedir (Luthans, 2002: 57). Pozitif örgütsel davranış günümüz çalışma ortamlarında performansın iyileştirilmesinde kullanılmak amacıyla ölçülebilecek, geliştirilebilecek ve etkin bir şekilde yönetilebilecek pozitif insan kaynaklarının güçlü yönlerinin ve psikolojik kabiliyetlerinin çalışılması ve hayata uygulanması olarak tanımlanmaktadır (Luthans, 2002: 59). Psikolojik sermaye bireyin olumlu psikolojik durumundaki gelişimi ifade etmektedir ve şu özelliklerle nitelendirilmektedir (Luthans vd., 2007a: 3):

- Bireyi zorlayacak görevlerin üstesinden gelecek biçimde gereken çabayı gösterebilme konusundaki öz yeterlilik (öz-yeterlilik), 
- Şimdi ve gelecekte başarılı olunacağı yönünde pozitif yaklaşım (iyimserlik),

- Başarılı olmak, hedefe yönelik kararlılık ve gerektiğinde hedefe giden yollarda değişiklik yapabilme yönünde ümitvar olmak (umut),

- Problemler ve olumsuzluklarla çepeçevre kuşatıldığında dahi başarıya ulaşmak için kendini toparlamak ve hatta eskisinden daha azimli olmak (dayanıkl1lik)

Psikolojik sermaye öz yeterlilik, iyimserlik, umut, dayanıklılık olarak dört alt boyuttan oluşmaktadır.

Öz yeterlilik, bireyin belirli bir bağlamda belirli bir görevi başarıyla yerine getirebilmek için harekete geçebilme (motivasyon), bilişsel kaynaklar ve gerekli adımları atabilme yeteneklerine sahip olduğu konusundaki inancıdır (Stajkovic ve Luthans, 1998b: 66; Avey vd., 2009: 680). İnanç ve güven düzeyi yüksek olan bireyler zorlu görevler karşısında dahi yılmadan çalışmakta ve hedeflerine ulaşmak için bütün güçlerini ortaya koymaktadırlar (Korkmazer vd., 2016: 272).

İyimserlik, hem gerçekçilik hem de esnekliktir. İyimserlik yaklaşımı, pozitif olayları kişisel, daimi ve sirayet edici sebeplerle, buna karşılık olumsuz durumları dışsal, geçici ve duruma özgü sebeplere ilişkilendirmektir. İyimserlik olumlu bir bakış açısı ile ilgilidir, fakat akılcı bir değerlendirme süzgecinden geçirilmeyen bir süreçte değildir (Avey vd., 2009: 681). İyimserlik haline sahip bireyin herhangi bir zorlukla karşılaşması durumunda hedefe ulaşmak için çabalamaya devam ettiği ve kötümser olanların ise çabalamayı bıraktıkları gözlemlenmiştir. İyimserlik genelde bir tutum ya da kişilik özelliği olarak da değerlendirilebilmektedir (Akdemir ve Açan, 2017: 60).

Umut, hem bireylerin hedeflerine ulaşma kararlılığı olarak iradeyi (azmi), hem de engeller karşısında herhangi bir amaca ulaşabilmek için alternatif yollar ve acil durum planları geliştirme niteliklerini ifade etmektedir (Avey vd., 2009: 681). Bu özellik çalışanların belirlenen hedeflere ulaşmasında pozitif ve motive edici bir rol oynamaktadır. Umut özelliği yüksek çalışanlar karşılaştıkları olumsuz olaylar karşısında farklı çözüm yolları aramakta, olumsuz bir durumla karşı karşıya kaldıklarında dahi bunu olumluya çevirmeye çalışmakta ve içinde bulundukları olayları bütün yönleriyle değerlendirmeye yönelmektedirler (Erkmen ve Esen, 2013: 24).

Psikolojik dayanıklılık, zorlukların üstesinden gelmeyi, güçlüklerden, çatışmalardan, başarısızlıklardan hatta olumlu olaylardan dahi kendini yenileyerek çıkmayı, daima ileriye yürümeyi ve artan sorumluluklar üstlenmeyi ifade eder ve geliştirilebilir bir kabiliyettir (Avey vd., 2009: 682). Psikolojik 
dayanıklılı̆ğ yüksek olan çalışanlar, yaşanan olumsuz durumlar içerisinde kendilerini kısa sürede tekrar toparlayarak görevlerine devam etmektedirler (Akdemir ve Açan, 2017: 62).

\section{İs Tatmini}

İş tatmini ile ilgili ilk çalışma 1932 yılında Robert Hoppock'un 80 katılımcının (40 çalışan, 40 işsiz) işleriyle ilgili hoşlandıkları ve hoşlanmadıkları noktaları belirlemek isteyen yarı yapılandırılmış çalışmadır denilebilir (İşsiz olanlara en son işlerini düşünerek cevap vermeleri istenmiştir). Bu çalışmada iş tatmininin işin toplumdaki statüsü, otonomi, üstler ve çalışma arkadaşları ile ilişkiler ile ilgili olduğu ortaya çıkmıştır (Bowling ve Cucina, 2015:110). İş tatmininin farklı tanımları söz konusudur. Cranny ve diğerleri iş tatminini, "bireyin işinde beklediği veya arzuladığ sonuçlarla gerçekleşen sonuçlar arasında yaptı̆̆ karşılaştırma temelinde işine karşı ortaya koyduğu duygusal tepki” olarak tanımlamaktadırlar (Cranny vd., 1992:1). Locke, iş tatminini "bireyin işi ve iş tecrübelerinden kaynaklanan hoşnutluk verici ya da olumlu duygusal durum" olarak tanımlamaktadır (Locke, 1976: 1304). Diğer bir şekilde bir tutum olarak iş tatmini insanların işlerinin değişik boyutlarından hoşlanma ve hoşnutsuzluklarının derecesidir (Spector, 1997: 2). İş tatmini, çalışanının işin gözetim, çalışma arkadaşları, işin kendisi, ücret ve terfi boyutları ile ilgili olumlu tutumları ve değerlendirmeleri olarak da tanımlanmaktadır (Porter vd., 1974: 605). Özellikle performans, işten ayrılma, devamsızlık ve örgüt etkinliği ile ilişkisinden dolayı (Lawler III, 1995: 91-95) örgütsel davranış literatüründe en fazla çalış1lan konulardan birisidir.

\section{Psikolojik Sermaye ve İş Tatmini Hakkında Literatür İncelemesi}

Psikolojik sermaye, çeşitli yönetsel uygulamalarda verilecek kararlara katkı sağlarken, bireysel ve örgütsel verimlilik ve performans artışlarına da olanak sunabilmektedir (Erkuş ve Fındıkl1, 2013:315). Avey vd. (2011:146) tarafından 51 bağımsız örneklemden oluşan bir meta-analiz çalışmasında psikolojik sermayenin performans üzerine etkisi açıkça ortaya konmuştur. Çalışmada psikolojik sermaye ile iş tatmini, örgütsel bağll1ık, psikolojik gönenç gibi arzulanan çalışan tutumları ile psikolojik sermaye arasında pozitif bir ilişki olduğu belirlenmiştir. Yine bu çalışmada sinizm, işten ayrılma niyeti, iş stresi ve endişe gibi istenmeyen çalışan davranışları ile psikolojik sermaye arasında negatif yönlü güçlü ilişki de ortaya konmuştur. Özellikle bu sonuçların hizmet sektöründe daha güçlü olduğu ortaya çıkmıştır.

Peterson vd. (2011:427) finans sektöründe yaptıkları boylamsal bir çalışmada psikolojik sermaye ile performans arasındaki pozitif yönlü ilişkinin varlığını tespit etmiş̧lerdir. Psikolojik sermaye ile iş tatmini arasında pozitif yönlü ilişkiyi ortaya koyan çok sayıda çalışma da mevcuttur. Luthans vd. (2008:232) üç 
çalışmayı rapor ettikleri bir makalede psikolojik sermaye ve iş tatmini arasında istatistiksel olarak anlamlı, orta ve güçlü düzeyde ilişkinin varlığını belirlemişlerdir.

Erkuş ve Fındıklı (2013:314) altı farklı meslek (polis, doktor, hemşire, öğretmen, laborant ve akademisyen) grubundan oluşan bir örneklemle yaptıkları çalışmada psikolojik sermaye ile iş tatmini arasında pozitif, işten ayrılma niyeti arasında negatif anlamlı ilişkilerin varlığına ulaşmışlardır. Kaplan ve Biçkes (2013: 238) hizmet sektöründe yaptıkları bir çalışmada psikolojik sermayenin alt boyutlarından dayanıklılık ve iyimserlik ile iş tatmini arasında pozitif yönlü anlamlı ilişki olduğu bulgusuna ulaşmışlardır. Badran ve Youssef-Morgan (2015:354) Mısır'da yaptıkları çalışmada psikolojik sermayenin bütün alt boyutlarının iş tatmini ile pozitif ilişkisinin varlığını tespit etmiştir.

Bergheim vd., (2014:32) gemi çalışanlarından oluşan bir örneklem üzerine yaptıkları çalışmada psikolojik sermaye ile iş tatmini arasında pozitif yönlü bir ilişki bulunmuştur. Çetin (2011: 377) kamu çalışanlarının örneklemi oluşturduğu bir çalışmada psikolojik sermayenin alt boyutları dayanıklılık, umut ve iyimserlik ile iş tatmini arasında pozitif yönlü ilişki olduğu bulgusuna ulaşmıştır.

Kwok vd. (2015: 574) Çin'de beyaz yakalı çalışanlarla yaptıkları bir çalışmada psikolojik sermayenin ümit, öz yeterlilik ve iyimserlik boyutlarının iş tatmini ile orta düzeyde pozitif ve anlamlı ilişki içerisinde olduğunu, buna karşın dayanıklılıkla iş tatmini arasında ise anlamlı bir ilişkinin olmadığ bulgusuna ulaşmışlardır. Larson ve Luthans (2006: 55) bir teknoloji firması çalışanlarının katılımcıları oluşturduğu bir çalışmada psikolojik sermayenin hem bir bütün olarak, yine psikolojik sermayenin alt boyutlarından ümit ve dayanıklılık alt boyutlarının da iş tatmini ile anlamlı ve pozitif ilişkisinin varlığını belirlemişlerdir. Şen vd. (2017: 177) kamu çalışanlarının katıldığı bir çalışmada psikolojik sermaye ile iş tatmini arasında anlamlı ve pozitif bir ilişki belirlemişlerdir. Literatürdeki bu bulgular doğrultusunda aşağıdaki hipotezler geliştirilmiştir.

Hipotez 1: Çalışmaya katılan sağlık çalışanlarının psikolojik sermaye düzeyleri ile iş tatmin düzeyleri arasında pozitif ve anlamlı ilişki vardır.

Hipotez 1a: Çalışmaya katılan sağlık çalışanlarının psikolojik sermaye alt boyutu özyeterlilik düzeyi ile iş tatmini arasında anlamlı ve pozitif ilişki vardır.

Hipotez 1b: Çalışmaya katılan sağlik çalışanlarının psikolojik sermaye alt boyutu umut düzeyi ile iş tatmini arasında anlamlı ve pozitif ilişki vardır.

Hipotez 1c: Çalı̧̧maya katılan sağlık çalışanlarının psikolojik sermaye alt boyutu iyimserlik düzeyi ile iş tatmini arasında anlamlı ve pozitif ilişki vardır. 
Hipotez 1d: Çalışmaya katılan sağlık çalışanlarının psikolojik sermaye alt boyutu dayanıklılık düzeyi ile iş tatmini arasında anlamlı ve pozitif ilişki vardır.

\section{YÖNTEM}

Tanımlayıcı tipteki bu araştırma tarama modeli ile gerçekleştirilmiştir. Bu çalışma sağlık çalışanlarında psikolojik sermaye ile iş tatmini arasındaki ilişkiyi belirlemek ve sağlık çalışanlarının psikolojik sermaye düzeylerini tespit etmek amacıyla yapılmıştır. Araştırmanın evreni ve örneklemini 2019 yılında Kahramanmaraş ilindeki bir kamu hastanesinde çalışmakta olan 180 sağlık çalışanı oluşturmaktadır. Veri toplama aracı olarak kişisel bilgi formu, psikolojik sermaye ölçeği ve iş tatmini ölçeği kullanılmıştır. Psikolojik sermayeyi ölçmek için Luthans vd., (2007) tarafından geliştirilen, Çetin ve Basım (2012) tarafından Türkçe'ye uyarlama çalışması yapılan ve Büyükgöze (2014)'nin çalışmasında kullandığı ölçekten yararlanılmıştır.

İş tatmini ölçmek için ise, Hackman ve Oldman (1975) İş Özellikleri anketinden yararlanılarak Türkçe'ye uyarlama çalışması Basım ve Şeşen (2009) tarafından yapılmış olan ve Çetin (2011)'nin çalışmasında kullanmış olduğu İş̧ Tatmini ölçeğinden faydalanılmıştır. Psikolojik sermaye ölçeği umut, iyimserlik, öz yeterlilik ve dayanıklılık alt boyutlarından oluşmaktadır. Kullanılan ölçeklere ait güvenirlik analizi sonuçları ve normallik dağılımı değerlerini gösteren Skewnees (çarpıklık), Kurtosis (basıklık) değerleri Tablo 1'de gösterilmiştir. Güvenilirlik analizi sonuçlarına göre bulunan değerler kullanılan ölçeklerin güvenilir olduğunu göstermektedir. Araştırmaya başlamadan önce Kahramanmaraş Sütçü İmam Üniversitesi Sosyal Bilimler Etik Kurulu'dan 22/03/2018 tarihli ve E.12539 sayılı etik kurul izni ile araştırmanın yapıldığ 1 kurumlardan yazılı izinler alınmıştır. Veriler anket yardımıyla, katılımcılardan gönüllülük esası dikkate alınarak elde edilmiştir. Toplanan veriler SPSS 21 paket programıyla analiz edilmiştir.

Tablo 1. Araştırmada Kullanılan Ölçeklerin Güvenirlik Analizi Ve Normal Dağılım Değerleri

\begin{tabular}{lcccc}
\hline & $\begin{array}{c}\text { Cronbach’s } \\
\text { Alpha Değeri }\end{array}$ & Skewnees & Kurtosis & $\begin{array}{c}\text { Std } \\
\text { Jeviation }\end{array}$ \\
\hline İyimserlik & 0,61 & $-0,218$ & $-0,694$ & 1,03 \\
\hline Psikolojik dayanıklılık & 0,77 & $-0,313$ & $-0,682$ & 0,92 \\
\hline Umut & 0,74 & $-0,325$ & $-0,538$ & 0,88 \\
\hline Öz yeterlilik & 0,84 & $-0,311$ & $-0,808$ & 0,98 \\
\hline Psikolojik sermaye & 0,91 & $-0,315$ & $-0,555$ & 0,82 \\
\hline İș tatmini & 0,88 & 0,415 & $-0,924$ & 1,12 \\
\hline
\end{tabular}


Analiz işlemi yapılmadan önce verilerin normal dağılım gösterip göstermediği kontrol edilmiş, çarpıklık ve basıklık değerlerinin $-1,5$ ile $+1,5$ arasında değer aldıkları görülmüştür (Tabachnick ve Fidell, 2013). Kullanılan analiz yöntemlerinde sayı-yüzdelik hesaplama, frekans, t testi, tek yönlü varyans analizi ve pearson korelasyon analizi yöntemlerinden yararlanılmıştır.

\section{BULGULAR VE TARTIŞMA}

Katılımcıların sosyo-demografik özellikleri ile iş tatmini ölçeği, psikolojik sermaye ölçeği puan ortalamaları, $t$ testi ve tek yönlü varyans analizi sonuçları Tablo 2'de gösterilmiştir. Katılımcıların \%51,1'i erkek (92 kişi), \%48,9'u ise (88 kişi) kadındır. Tablo 2 incelendiğinde psikolojik sermaye puan ortalaması ile cinsiyet arasında istatistiksel olarak anlamlı bir farklılık saptanmıştır. Psikolojik sermaye ölçeği puan ortalaması erkek katılımcılarda $(2,90 \pm 1,18)$ anlamlı düzeyde daha yüksek bulunmuştur. Buna karşın Yıldız ve Örücü (2016:278) sağlık çalı̧̧anlarında psikolojik sermaye düzeylerinin belirlenmesine yönelik çalışmasında cinsiyet ile psikolojik sermaye arasında anlamlı bir farklılık bulamamışlardır.

Katılımcıların \%70,6'sı (127 kişi) evli, \%29,4'ü bekârdır (53 kişi). Psikolojik sermaye ölçeği incelendiğinde katılımcıların medeni durumları ile psikolojik sermaye arasında istatistiksel olarak anlamlı bir farklılık saptanmamıştır ve literatür ile uyumludur (Zağl1, 2016: 104).

Katılımcıların \% 42,2'si 21-30 yaş aralığında, \%39,4'ü 31-40 yaş aralığında \%12,8'nin ise 41-50 yaş aralığında olduğu bulgulanmıştır (Tablo 2). Tablo 2'de katılımcıların yaşları ile psikolojik sermaye düzeyleri arasında anlamlı bir farklılık olduğu belirlenmiştir. Psikolojik sermaye ölçeği puan ortalaması yaş değişkeni alt gruplarına göre 41-50 yaş arası $(4,91 \pm 0,68)$ olanlarda anlamlı düzeyde daha yüksek olduğu görülmüştür. Gruplar arası farklılıkları belirlemek için yapılan Tukey testi sonucuna göre katılımcıların psikolojik sermaye düzeylerinin yaş değişkeni alt gruplarında 21-30 yaş aralığında olanlar ile 41-50 yaş arası grup lehine istatiksel olarak anlamlı düzeyde bir farklılık olduğu bulgulanmıştır. Erkmen ve Esen (2012: 65) bilişim sektöründeki çalışanlarda psikolojik sermaye düzeyleri ile yaş demografik değişkeni arasında anlamlı bir farklılaşma olduğu ve psikolojik sermaye puan ortalamasının 38 ve üstü yaş grubunda anlamlı düzeyde daha yüksek bulgusuna ulaşmışlardır.

Tablo 2'de görülebileceği gibi katılımcıların \%39,4'ü lisans, \%25'i ön lisans ve $\% 14,4$ 'ü lisansüstü eğitimi mezunudur. Katılımcıların eğitim durumları ile psikolojik sermaye düzeyleri arasında istatistiksel olarak anlamlı bir farkl111k saptanamamıştır. Büyükgöze (2014:79)' nin lise öğretmenleri üzerindeki çalışmasında da katılımcıların psikolojik sermaye düzeyleri ile eğitim durumları arasında anlamlı bir farklılık görülmemiştir. Bu çalışmaya katkıda bulunanların 
\%54,4'ünü hemşireler, \%14,4'ünü sağl1k teknisyenleri, \%11,7'sini tıbbi sekreterler, \%11,1'i ise doktorlar oluşturmaktadır. Yine Tablo 2'de görülebileceği gibi psikolojik sermaye ölçeği ile katılımcıların çalışma statüsü arasında anlamlı bir farklılık bulunmamıştır.

Tablo 2: Katılımcıların demografik özellikleriyle psikolojik sermaye ve iş tatmini ölçeği analizi tablosu

\begin{tabular}{|c|c|c|c|c|c|c|}
\hline \multirow{4}{*}{$\begin{array}{l} \\
\text { Cinsiyet * } \\
\text { Kadın } \\
\text { Erkek }\end{array}$} & $\mathrm{N}$ & $\%$ & \multirow{2}{*}{\multicolumn{2}{|c|}{$\begin{array}{l}\text { İş Tatmini } \\
\text { Mean } \pm \text { ss }\end{array}$}} & \multicolumn{2}{|c|}{ Psikolojik sermaye } \\
\hline & & & & & \multicolumn{2}{|l|}{ Mean \pm ss } \\
\hline & 88 & 48,9 & $2,68 \pm 1,04$ & $\mathrm{P}: 0,18$ & $4,23 \pm 0,87$ & \\
\hline & 92 & 51,1 & $2,90 \pm 1,18$ & $\begin{array}{l}0 \quad \text { t:- } \\
1,345\end{array}$ & $4,74 \pm 0,69$ & $\mathrm{t}:-4,320$ \\
\hline
\end{tabular}

\section{Medeni durum*}

\begin{tabular}{|c|c|c|c|c|c|c|}
\hline $\begin{array}{l}\text { Evli } \\
\text { Bekâr }\end{array}$ & 127 & $\begin{array}{c}70,6 \\
29,4\end{array}$ & $\begin{array}{l}2,78 \pm 1,14 \\
2,82 \pm 1,07\end{array}$ & $\begin{array}{l}\mathrm{P}: 0,81 \\
9 \\
\mathrm{t}:- \\
0,229\end{array}$ & $\begin{array}{l}4,51 \pm 0,82 \\
4,45 \pm 0,83\end{array}$ & $\begin{array}{l}\mathrm{P}: 0,643 \\
\mathrm{t}: 0,464\end{array}$ \\
\hline \multicolumn{7}{|l|}{ Yaş ** } \\
\hline $16-20$ yaş & 10 & 5,6 & $2,84 \pm 1,15$ & $P: 0,23$ & $4,31 \pm 0,65$ & \multirow{4}{*}{$\begin{array}{l}\mathbf{P}: \mathbf{0 , 0 3 8} \\
F: 2,865\end{array}$} \\
\hline $21-30$ yaş & 76 & 42,2 & $2,60 \pm 1,11$ & 9 & $4,36 \pm 0,87$ & \\
\hline $31-40$ yaş & 71 & 39,4 & $2,90 \pm 1,14$ & $\mathrm{~F}: 1,41$ & $4,53 \pm 0,79$ & \\
\hline $41-50$ yaş & 23 & 12,8 & $3,07 \pm 1,00$ & 8 & $4,91 \pm 0,68$ & \\
\hline \multicolumn{7}{|l|}{$\begin{array}{l}\text { Eğitim } \\
\text { durumu** }\end{array}$} \\
\hline Lise & 38 & 21,1 & $2,99 \pm 1,26$ & $P: 0,60$ & $4,50 \pm 0,91$ & \multirow{4}{*}{$\begin{array}{l}P: 0,745 \\
F: 0,412\end{array}$} \\
\hline Ön lisans & 45 & 25,0 & $2,66 \pm 1,08$ & 9 & $4,52 \pm 0,84$ & \\
\hline Lisans & 71 & 39,4 & $2,78 \pm 1,11$ & $F: 0,61$ & $4,43 \pm 0,83$ & \\
\hline Lisansüstü & 26 & 14,4 & $2,78 \pm 0,98$ & 1 & $4,63 \pm 0,59$ & \\
\hline \multicolumn{7}{|l|}{$\begin{array}{l}\text { Çalışma } \\
\text { statüsü** }\end{array}$} \\
\hline T1bbi sekreter & 21 & 11,7 & $2,92 \pm 1,19$ & & $4,60 \pm 0,74$ & \multirow{5}{*}{$\begin{array}{l}\mathrm{P}: 0,354 \\
\mathrm{~F}: 1,109\end{array}$} \\
\hline Sağlik teknisyeni & 26 & 14,4 & $2,92 \pm 1,20$ & & $4,58 \pm 0,78$ & \\
\hline Doktor & 20 & 11,1 & $2,66 \pm 0,87$ & & $4,63 \pm 0,57$ & \\
\hline Hemşire & 98 & 54,4 & $2,64 \pm 1,07$ & $\begin{array}{l}\mathrm{F} \\
2\end{array}$ & $4,38 \pm 0,86$ & \\
\hline Diğer & 15 & 8,3 & $3,54 \pm 1,27$ & & $4,75 \pm 0,93$ & \\
\hline \multicolumn{7}{|l|}{$\begin{array}{l}\text { Bulunduğu } \\
\text { hastanede } \\
\text { çalışma süresi ** }\end{array}$} \\
\hline $0-1$ y1l & 16 & 8,9 & $2,25 \pm 1,00$ & $P: 0,21$ & $4,07 \pm 0,90$ & P:0,011 \\
\hline $2-5$ y1l & 87 & 48,3 & $2,74 \pm 1,05$ & 5 & $4,41 \pm 0,80$ & $F: 3,390$ \\
\hline
\end{tabular}




\begin{tabular}{lllllll} 
6-10 y1l & 52 & 28,9 & $2,96 \pm 1,17$ & $\mathrm{~F}: 1,46$ & $4,60 \pm 0,73$ & \\
$11-15$ y1l & 12 & 6,7 & $3,00 \pm 1,46$ & 4 & $4,61 \pm 0,86$ & \\
16 y1l ve üzeri & 13 & 7,2 & $2,95 \pm 1,08$ & & $5,08 \pm 0,86$ \\
\hline
\end{tabular}

\begin{tabular}{lllllll}
$\begin{array}{l}\text { Toplam mesleki } \\
\text { çalışma yılı** }\end{array}$ & & & & & & \\
2-5 y1l & 55 & 30,6 & $2,50 \pm 1,06$ & $\mathrm{P}: 0,13$ & $4,26 \pm 0,80$ & \\
6-10 y1l & 50 & 27,8 & $2,90 \pm 1,12$ & 3 & $4,46 \pm 0,92$ & $\mathbf{P : 0 , 0 1 3}$ \\
11-15 y1l & 46 & 25,6 & $3,00 \pm 1,25$ & $\mathrm{~F}: 1,88$ & $4,58 \pm 0,61$ & $\mathrm{~F}: 3,704$ \\
16 y1l ve üzeri & 29 & 16,1 & $2,84 \pm 0,94$ & 9 & $4,85 \pm 0,86$ & \\
\hline Aylık gelir** & & & & & & \\
1000-2000 TL & 30 & 16,7 & $3,01 \pm 1,31$ & $\mathrm{P}: 0,55$ & $4,60 \pm 0,85$ & \\
2001-4000 TL & 67 & 37,2 & $2,69 \pm 1,12$ & 2 & $4,29 \pm 0,86$ & $\mathrm{P}: 0,090$ \\
4001-6000 TL & 62 & 34,4 & $2,84 \pm 1,10$ & $\mathrm{~F}: 0,70$ & $4,62 \pm 0,81$ & $\mathrm{~F}: 2,196$ \\
6001 TL ve üzeri & 21 & 11,7 & $2,65 \pm 0,84$ & 2 & $4,63 \pm 0,55$ & \\
\hline
\end{tabular}

*T Testi ** Anova Testi *** Gruplar arası farklılığa Tukey testi ile bakılmıştır. $P<0,05$

Katılımcıların bulundukları kurumda çalışma süreleri ile ilgili olarak \%48,3'ünün 2-5 y1l aras1, \%28,9'unun 6-10 y1l aras1 görev yaptıklar1 görülmektedir. Tablo 2'de görüldügü gibi katılımciların bulundukları kurumda çalışma süreleri ile psikolojik sermaye arasında istatistiksel olarak anlamlı bir farkl1lık belirlenmiştir ve bu sonuç literatürle uyum göstermektedir. Nitekim Yıldız ve Örücü (2016:269) çalışmasında katılımcıların psikolojik sermaye düzeyleri ile bulundukları kurumdaki çalışma süresi arasında istatistiksel olarak anlamlı bir farklılık olduğu tespit edilmiştir.

Psikolojik sermaye ölçeği puan ortalaması bulundukları kurumda çalışma süreleriyle ilgili gruplarda 16 yıl ve üzeri olanlarda istatistiksel olarak anlamlı düzeyde daha yüksektir. Tukey testi sonucunda bulundukları kurumda çalışma sürelerine ait alt gruplarda $0-1$ yıl ve 2-5 y1l arası çalışanlar ile 16 yıl ve üzeri çalışanlar arasında, 16 yıl ve üzeri grup lehine istatiksel olarak anlamlı düzeyde bir farklılık olduğu belirlenmiştir. Literatürde de bu bulguyu destekleyen sonuç bulunmaktadır. Nitekim Rego vd., (2010) tarafindan Portekiz'de yapılan 278 inşaat mühendisinin katkıda bulunduğu çalışmada da kurumdaki çalışma süresi ile genel olarak psikolojik sermaye düzeyi ve iyimserlik, ümit ve dayanıklılık alt boyutları arasında pozitif bir iliş̧i olduğu bulgusuna ulaşılmıştır.

Katılımcıların toplam mesleki çalışma yılına bakıldığında \%30,6'sının 2-5 yıl arası, \%27,8'inin 6-10 yıl arası, \%25,6'sının ise 11-15 yıl arası çalışma sürelerine sahip oldukları belirlenmiştir (Tablo 2). Katılımcıların psikolojik sermaye ölçeği ile toplam mesleki çalışma yılı arasında istatistiksel olarak anlamlı bir farklılık bulunmuştur. Psikolojik sermaye ölçeğinin puan ortalaması toplam mesleki yılı 
çalışma süreleri alt gruplarına göre 16 yıl ve üzeri olan çalışanlarda $(4,85 \pm 0,86)$ anlamlı düzeyde daha yüksektir ve literatürle uyum gösteren bir bulgudur (Erkmen ve Esen, 2012: 64). Tukey testi sonucuna göre toplam mesleki y1lı çalışma süreleri alt gruplarında 0-1 yıl arası çalışanlar ile 16 yıl ve üzeri çalışanlar arasında bu grup lehine ortalamanın daha yüksek olduğu saptanmıştır. Yine Tablo 2'de katılımcıların aylık gelirleri incelendiğinde \%37,2'sinin 2001-4000 TL aras1, \%34,6'sinin 4001-6000 TL aras1, \%16,7'sinin ise 1000-2000 TL arasinda geliri olduğu belirlenmiştir. Psikolojik sermaye ölçeği ile katılımcıların aylık gelirleri arasında istatistiksel olarak anlamlı bir farklılık olmadığı görülmüştür. Tablo 2'de görüldüğü gibi katılımcıların cinsiyet, yaş, eğitim düzeyi, çalışma statüsü, bulundukları kurumda çalışma süresi, toplam mesleki yılı ve aylık gelirleri ile iş tatmini ölçeği arasında anlamlı bir farklılık bulunamamıştır.

Tablo 3: Cinsiyet Demografik Değişkeni İle Psikolojik Sermaye Ölçeği Alt Boyutları T Testi Analizi

\begin{tabular}{ccccc}
\hline Ölçek alt boyutları & Kadın (n:88) & Erkek (n:92) & T değeri & P değeri \\
\hline & Ortalama \pm ss & Ortalama \pm ss & & \\
Umut Boyutu* $^{*} 4,28 \pm 0,93$ & $4,73 \pm 0,78$ & t:-3,494 & P:0,001 \\
Öz Yeterlilik* & $4,25 \pm 1,05$ & $4,88 \pm 0,81$ & t: $-4,490$ & $\mathbf{P : 0 , 0 0 0}$ \\
İyimserlik * & $4,07 \pm 1,08$ & $4,46 \pm 0,94$ & t:-2,543 & $\mathbf{P : 0 , 0 1 2}$ \\
sikolojik Dayanıklılık* & $4,33 \pm 1,01$ & $4,90 \pm 0,73$ & $\mathrm{t}:-4,318$ & $\mathbf{P : 0 , 0 0 0}$ \\
\hline
\end{tabular}

*T Testi, $P<0,05$

Katılımcıların cinsiyetleri ile psikolojik sermaye ölçeği alt boyutları t testi analiz sonuçları Tablo 3 'te gösterilmektedir. Tablo 3 incelendiğinde psikolojik sermaye ölçeği alt boyutlarından umut, öz yeterlilik, iyimserlik ve psikolojik dayanıklılık alt boyutları ile cinsiyet arasında anlamlı bir farklılık olduğu tespit edilmiştir. Psikolojik sermaye ölçeği alt boyutlarından puan ortalaması erkek katılımcılar için sırasıyla umut boyutu $(4,73 \pm 0,78)$, öz yeterlilik boyutu $(4,88 \pm 0,81)$, iyimserlik boyutu $(4,46 \pm 0,94)$ psikolojik dayanıllılık boyutu ise $(4,90 \pm 0,73)$ olarak, kadın katılımcılara göre anlamlı düzeyde daha yüksek olduğu belirlenmiştir.

Tablo 4: Yaş Değişkeni İle Psikolojik Sermaye Ölçeği Alt Boyutu Analiz Sonuçları

\begin{tabular}{lllllll}
\hline & $\begin{array}{l}16-20 \text { yaş } \\
(\mathrm{n}: 10)\end{array}$ & $\begin{array}{l}21-30 \text { yaş } \\
(\mathrm{n}: 76)\end{array}$ & $\begin{array}{l}31-40 \text { yaş } \\
(\mathrm{n}: 71)\end{array}$ & $\begin{array}{l}41-50 \text { yaş } \\
(\mathrm{n}: 23)\end{array}$ & Test değeri \\
\hline $\begin{array}{l}\text { Umut } \\
\text { Boyutu** }\end{array}$ & $4,18 \pm 0,83$ & $4,38 \pm 0,89$ & $4,57 \pm 0,89$ & $4,94 \pm 0,72$ & $\mathrm{~F}: 2,987$ & $\mathbf{P : 0 , 0 3 3}$ \\
\hline Öz & $4,30 \pm 0,73$ & $4,40 \pm 1,03$ & $4,60 \pm 0,97$ & $5,18 \pm 0,73$ & $\mathrm{~F}: 4,140$ & $\mathbf{P : 0 , 0 0 7}$ \\
Yeterlilik** & & & & & & \\
\hline
\end{tabular}




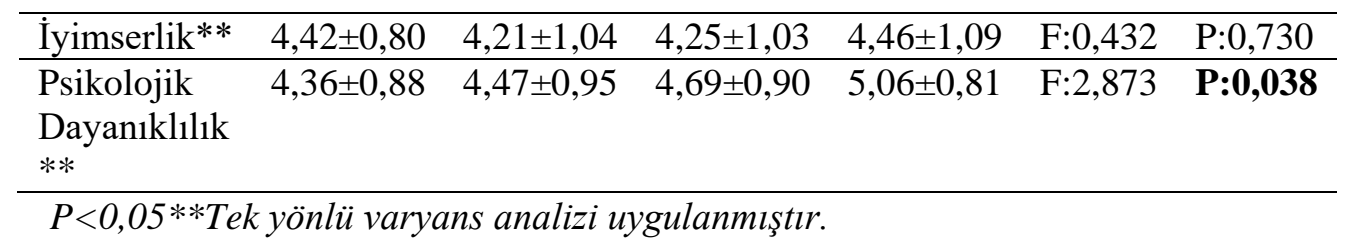

Katılımcıların psikolojik sermeye ölçeği alt boyutları ile yaş demografik değişkeni arasındaki tek yönlü varyans analizi (Anova) sonuçları Tablo 4'te gösterilmektedir. Katılımcıların yaşları ile ölçek alt boyutlarından umut, öz yeterlilik ve psikolojik dayanıklılık alt boyutu arasında istatistiksel olarak anlamlı bir farklılık olduğu bulunurken, katılımcıların yaşları ile iyimserlik boyutu arasında istatistiksel olarak anlamlı bir farklılık olmadığı saptanmıştır. Kara Uğurlu (2014:68)'nun çalışmasında ise katılımcıların psikolojik sermaye alt boyutları ile yaş değişkeni arasında anlamlı bir farklılık tespit edilmemiştir. Ölçek alt boyutları puan ortalaması 41-50 yaş arası olan grubun diğer yaş gruplarına göre karşılaştırıldığında sırasıyla umut boyutunda $(4,94 \pm 0,72)$, öz yeterlilik boyutunda $(5,18 \pm 0,73)$ ve psikolojik dayanıkl1lk boyutunda $(5,06 \pm 0,81)$ olmak üzere anlamlı düzeyde daha yüksek bulunmuştur. Tukey testi sonucu yaş grupları içerisinde 21-30 yaş arası grup ile 41-50 yaş arası grup arasında sırasıyla umut, öz yeterlilik ve psikolojik dayanıklılık alt boyutlarında ikinci grup lehine anlamlı düzeyde bir farklılık saptanmıştır.

Tablo 5: Toplam Mesleki Çalışma Yılı İle Ölçek Alt Boyutları Anova Testi Analizi

\begin{tabular}{|c|c|c|c|c|c|c|}
\hline & $\begin{array}{l}2-5 \text { y1l } \\
\text { (n:55) }\end{array}$ & $\begin{array}{l}\text { 6-10 y1l } \\
\text { (n:50) }\end{array}$ & $\begin{array}{l}11-15 \text { y1l } \\
(\mathrm{n}: 46)\end{array}$ & $\begin{array}{l}16 \text { y1l ve } \\
\text { üzeri } \\
(\mathrm{n}: 29)\end{array}$ & & \\
\hline $\begin{array}{l}\text { Umut } \\
\text { Boyutu** }\end{array}$ & $4,32 \pm 0,82$ & $4,44 \pm 0,97$ & $4,60 \pm 0,83$ & $4,88 \pm 0,85$ & P:0,037 & $F: 2,895$ \\
\hline $\begin{array}{l}\text { Öz } \\
\text { Yeterlilik** }\end{array}$ & $4,26 \pm 0,98$ & $4,50 \pm 1,06$ & $4,76 \pm 0,74$ & $5,00 \pm 1,01$ & P:0,004 & F:4,582 \\
\hline İyimserlik** & $4,10 \pm 0,95$ & $4,40 \pm 1,07$ & $4,16 \pm 1,03$ & $4,56 \pm 1,05$ & P:0,166 & $\mathrm{F}: 1,713$ \\
\hline $\begin{array}{l}\text { Psikolojik } \\
\text { Dayanıklılık } \\
* *\end{array}$ & $4,36 \pm 0,91$ & $4,53 \pm 0,98$ & $4,81 \pm 0,77$ & $4,98 \pm 0,93$ & P:0,011 & $\mathrm{F}: 3,833$ \\
\hline
\end{tabular}

Tablo 5'te katılımcıların psikolojik sermaye ölçeği alt boyutları ile toplam mesleki yılları değişkeni ile yapılan tek yönlü varyans analizi (Anova) sonuçları gösterilmiştir. Toplam mesleki yıl ile umut, öz yeterlilik, psikolojik dayanıkl1lık alt boyutları arasında istatistiksel olarak anlamlı bir farklılık olduğu görülürken, toplam mesleki yıl ile iyimserlik alt boyutu arasında anlamlı bir farklılık 
bulunmamıştır. Ölçek alt boyutlarından umut, öz yeterlilik ve psikolojik dayanıklılık alt boyutları puan ortalaması toplam mesleki çalışma yılı 16 yıl ve üzeri olan çalışanlarda anlamlı düzeyde daha yüksek bulunmuştur. Tukey testi sonucuna göre sirasıyla umut ve psikolojik dayanıklılık alt boyutlarında toplam mesleki çalışma yılı alt gruplarında 2-5 yıl arası çalışan grubu ile 16 yıl ve üzeri çalışanlar arasında, ikinci grup lehine anlamlı bir farklılık olduğu belirlenmiştir. Tukey testi sonucunda öz yeterlilik alt boyutu incelendiğinde toplam mesleki çalışma yılı alt grupları arasında 2-5 yıl arası çalışanların 11-15 yıl arası ve 16 yıl ve üzeri çalışan gruplar arasında istatiksel olarak anlamlı bir farklılık olduğu belirlenmiştir. Akman (2016: 273) çalışmasında ölçek alt boyutlarından öz yeterlilik, umut boyutuyla toplam mesleki yıl süreleri ile aralarında anlamlı bir farklılık bulunurken, iyimserlik ve psikolojik dayanıklılık boyutuyla aralarında anlamlı bir farklılık bulunmamıştır.

Tablo 6: Katılımcıların Bulundukları Kurumda Çalışma Süresi Ölçek Alt Boyutları Analizi Sonuçları

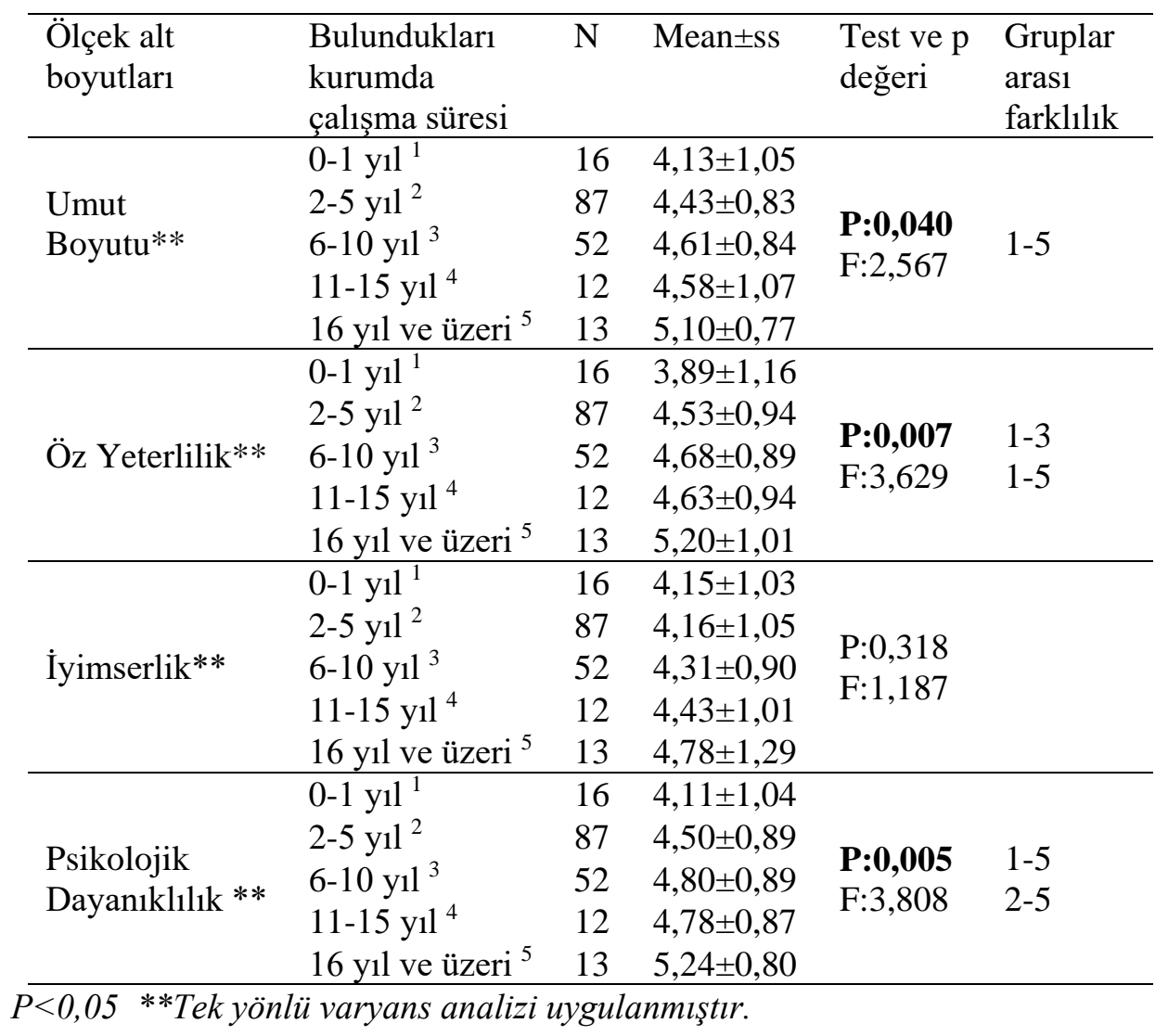


Tablo 6'da katılımcıların bulundukları kurumda çalışma süreleri ile ölçek alt boyutlarının tek yönlü varyans analizi (Anova) sonuçları gösterilmektedir. Katılımcıların bulundukları kurumda çalışma süreleri ile ölçek alt boyutlarından umut, öz yeterlilik ve psikolojik dayanıklılık alt boyutları arasında istatistiksel olarak anlamlı bir farklılık bulunurken, bulundukları kurumda çalışma süreleri ile iyimserlik boyutu arasında istatistiksel olarak anlamlı bir farklılık bulunmamıştır. Ölçek alt boyutlarından umut, öz yeterlilik ve psikolojik dayanıklılık alt boyutları puan ortalaması bulundukları kurumda çalışma süresi 16 yıl ve üzeri olan çalışanlarda anlamlı düzeyde daha yüksek bulunmuştur. Tukey testi sonucuna göre bulundukları kurumda çalışma süresi alt gruplarında umut alt boyutunda 031 yıl arası çalışanların 16 yıl ve üzeri çalışanlara göre anlamlı bir şekilde farklılaştı̆̆ saptanmıştır. Öz yeterlilik alt boyutunda ise bulundukları kurumda çalışma süresi alt gruplarında 0-1 yıl arası çalışanların 6-10 yıl ve 16 yıl ve üzeri çalışanlara göre anlamlı düzeyde farklılaştığı belirlenmiştir. Aynı şekilde psikolojik dayanıklılık boyutunda ise, $0-1$ yıl arası ile 16 yıl ve üzeri çalışanlara göre, 2-5 yıl arası çalışanların ise 16 yıl ve üzeri çalışanlara göre gruplar arası anlamlı düzeyde bir farkl1lık olduğu görülmüştür.

Tablo 7'de psikolojik sermaye ölçeği ve alt boyutlarının iş tatmini ile olan ilişkisi ve psikolojik sermaye ölçeğinin alt boyutlarının birbirleriyle olan ilişkisi gösterilmiştir.

Tablo 7: Psikolojik Sermaye Ölçeği ve Alt Boyutlarının İş Tatmini İle Olan İlişkisi

\begin{tabular}{|c|c|c|c|c|c|c|c|}
\hline $\begin{array}{l}\text { Ölçek ve } \\
\text { alt } \\
\text { boyutları }\end{array}$ & & (1) & (2) & (3) & (4) & (5) & (6) \\
\hline Umut (1) & $\begin{array}{l}\mathrm{r} \\
\mathrm{p}\end{array}$ & 1 & $\begin{array}{l}0,774^{* *} \\
0,000\end{array}$ & $\begin{array}{l}0,620^{* *} \\
0,000\end{array}$ & $\begin{array}{l}0,797 * * \\
0,000\end{array}$ & $\begin{array}{l}0,921^{* *} \\
0,000\end{array}$ & $\begin{array}{l}0,562 * * \\
0,000\end{array}$ \\
\hline $\begin{array}{l}\text { Öz } \\
\text { yeterlilik } \\
\text { (2) }\end{array}$ & $\begin{array}{l}\mathrm{r} \\
\mathrm{p}\end{array}$ & $\begin{array}{l}0,774^{* *} \\
0,000\end{array}$ & 1 & $\begin{array}{l}0,507^{* *} \\
0,000\end{array}$ & $\begin{array}{l}0,751^{* *} \\
0,000\end{array}$ & $\begin{array}{l}0,879 * * \\
0,000\end{array}$ & $\begin{array}{l}0,436^{* *} \\
0,000\end{array}$ \\
\hline $\begin{array}{l}\text { İyimserlik } \\
\text { (3) }\end{array}$ & $\begin{array}{l}r \\
p\end{array}$ & $\begin{array}{l}0,620^{* *} \\
0,000\end{array}$ & $\begin{array}{l}0,507 * * \\
0,000\end{array}$ & 1 & $\begin{array}{l}0,488 * * \\
0,000\end{array}$ & $\begin{array}{l}0,770^{* *} \\
, 000\end{array}$ & $\begin{array}{l}0,566^{* *} \\
0,000\end{array}$ \\
\hline $\begin{array}{l}\text { Psikolojik } \\
\text { Dayanıkl11ı } \\
\text { k (4) }\end{array}$ & $\begin{array}{l}\mathrm{r} \\
\mathrm{p}\end{array}$ & $\begin{array}{l}0,797 * * \\
0,000\end{array}$ & $\begin{array}{l}0,751^{* *} \\
0,000\end{array}$ & $\begin{array}{l}, 488 * * \\
, 000\end{array}$ & 1 & $\begin{array}{l}, 875^{* *} \\
, 000\end{array}$ & $\begin{array}{l}0,480 * * \\
0,000\end{array}$ \\
\hline $\begin{array}{l}\text { Psikolojik } \\
\text { sermaye (5) }\end{array}$ & $\begin{array}{l}\mathrm{r} \\
\mathrm{p}\end{array}$ & $\begin{array}{l}0,921^{* *} \\
0,000\end{array}$ & $\begin{array}{l}0,879 * * \\
0,000 \\
\end{array}$ & $\begin{array}{l}0,770^{* *} \\
0,000\end{array}$ & $\begin{array}{l}0,875^{* *} \\
0,000 \\
\end{array}$ & 1 & $\begin{array}{l}0,595^{* *} \\
0,000 \\
\end{array}$ \\
\hline $\begin{array}{l}\text { İş tatmini } \\
\text { (6) }\end{array}$ & $\begin{array}{l}r \\
p\end{array}$ & $\begin{array}{l}0,562 * * \\
0,000\end{array}$ & $\begin{array}{l}0,436 * * \\
0,000\end{array}$ & $\begin{array}{l}0,566^{* *} \\
0,000\end{array}$ & $\begin{array}{l}0,480 * * \\
0,000\end{array}$ & $\begin{array}{l}0,595^{* *} \\
0,000\end{array}$ & 1 \\
\hline
\end{tabular}

$N: 180 * * p<0,01$ 
Psikolojik sermaye ölçeği ile iş tatmini ölçeği arasında orta derecede neredeyse yüksek seviyede değerlendirebileceğimiz pozitif yönlü anlamlı bir ilişki olduğu tespit edilmiş (r:0,595; p:0,000) ve "Hipotez 1 " kabul edilmiştir. Bu bulgu literatürle uyum göstermektedir. Nitekim Larson ve Luthans (2006:) üretim işçileri üzerine yaptıkları çalışmada psikolojik sermaye ile iş tatmini arasında pozitif yönlü anlamlı bir ilişki tespit etmişlerdir. Luthans vd., (2008) üç farklı örneklemde yaptığı çalışmada psikolojik sermaye ile iş tatmini arasında pozitif yönlü bir ilişki belirlenmiştir. Türkiye'de yapılan psikolojik sermayenin iş tatminine olan ilişkisini belirlemeye yönelik bazı çalışmalarda da psikolojik sermaye ile iş tatmini arasında pozitif yönlü istatistiksel olarak anlamlı düzeyde bir ilişkinin varlığı belirlenmiştir (Akçay, 2012: 130; Erkuş ve Fındıklı, 2013: 310; Salha vd., 2016: 381).

Öz yeterlilik alt boyutu ile iş tatmini arasında orta derecede pozitif yönlü anlamlı bir ilişki olduğu belirlenmiş (r:0,436; p:0,000) ve "Hipotez 1a" kabul edilmiştir. ve literatür ile uyum gösteren bir bulgudur (Badran ve YoussefMorgan, 2015:354). Tablo 7 incelendiğinde ölçek alt boyutlarından umut alt boyutu ile iş tatmin ölçeği arasında pozitif yönlü anlamlı düzeyde orta derecede bir ilişki olduğu görülmüş (r:0,562; p:0,000) ve bu sonuca göre "Hipotez $1 \mathrm{~b}$ " kabul edilmiştir. Bu bulgu literatürle benzerlik göstermektedir (Akçay (2012: 130; Yeşil vd., 2016: 34). İyimserlik alt boyutu ile iş tatmini arasında pozitif yönlü anlamlı düzeyde orta derecede bir ilişki vardır (r:0,566; p:0,000). Bu bulgu doğrultusunda "Hipotez 1c" kabul edilmiştir. Bu bulguda literatürle benzerlik gösteren bir bulgudur (Youssef ve Luthans, 2007: 788; Akçay, 2012: 130). Psikolojik dayanıklılık alt boyutu ile iş tatmini arasında orta derecede pozitif yönlü anlamlı doğru bir ilişki olduğu belirlenmiştir (r:0,480; p:0,000) ve "Hipotez 1d" kabul edilmiştir. Youssef ve Luthans (2007: 788) iki farklı örneklem üzerinde yaptıkları çalışmada umut ve psikolojik dayanıklılık boyutları ile iş tatmini arasında buna ek olarak iyimserlik boyutu ile iş tatmini arasında da pozitif yönlü ve anlamlı düzeyde bir ilişki saptamışlardır. Kaplan ve Biçkes (2013: 238) çalışmasında psikolojik dayanıklılık ve iyimserlik boyutları ile iş tatmini arasında pozitif yönlü bir ilişki olduğunu belirlemişlerdir. Yine Badran ve YoussefMorgan (2015:354) ise psikolojik sermaye alt boyutlarının tamamının iş tatminini olumlu ve anlamlı düzeyde etkilediği bulgusuna ulaşmışlardır.

Psikolojik sermaye ölçeği ve alt boyutları ile iş tatmini ölçeğinde yer alan maddelere verilen cevaplar toplu şekilde değerlendirilerek aritmetik ortalaması alınmıştır (Tablo 8) ve psikolojik sermaye ölçeği için $(\bar{X}=4,49)$ ortalama değer elde edilmiştir. 
Tablo 8: Psikolojik Sermaye Ölçeği ve Alt Boyutlarının İş Tatmini İle Olan İlişkisi

\begin{tabular}{ccc}
\hline Ölçek ve alt boyutları & Mean \pm ss & $\begin{array}{c}\text { Standart } \\
\text { sapma }\end{array}$ \\
\hline Umut & $4,51 \pm 0,88$ & 0,88 \\
\hline Öz yeterlilik & $4,57 \pm 0,98$ & 0,98 \\
\hline İyimserlik & $4,27 \pm 1,03$ & 1,03 \\
\hline Psikolojik & $4,62 \pm 0,92$ & 0,92 \\
Dayanılılık & $4,49 \pm 0,82$ & 0,82 \\
\hline Psikolojik sermaye & $2,79 \pm 1,12$ & 1,12 \\
\hline İş tatmini & &
\end{tabular}

Buna göre boyut ortalamaları incelendiğinde umut boyutu aritmetik ortalamas1 $(\overline{\mathrm{X}}=4,51)$, öz yeterlilik boyutunda $(\overline{\mathrm{X}}=4,57)$, iyimserlik boyutunda $(\bar{X}=4,27)$ ve psikolojik dayanıkl11 k boyutunda ise $(\bar{X}=4,62)$ olarak bulunmuştur. Bulunan aritmetik ortalamadan hareketle katılımcıların psikolojik sermaye düzeylerinin umut, öz yeterlilik ve psikolojik dayanıklılık boyutlarının ortalama değerin üstünde olduğu iyimserlik boyutunun ise ortalama değerin altında olduğu görülmektedir.

Tablo 8'de sağlık çalışanlarının psikolojik sermaye puan ortalaması $(\overline{\mathrm{X}}=4,49 \pm 0,82)$ olarak bulunmuştur. Alan yazınında yapılan çalışmalar incelendiğinde; Karatepe Kuşcu vd. (2019: 110)'nin hemşireler üzerinde $\bar{X}=4,45 \pm 0,72$; Karaman vd. (2020: 137)'nin sağlık çalışanlarında $\bar{X}=4,71 \pm 0,63$; Korkmazer vd. (2016: 276)'nin sağlık çalışanlarında $\bar{X}=3,87 \pm 0,47$; Akdoğan ve Polatçı (2013: 283) akademisyen, doktor, hemşire, polis ve bankacılarda $\overline{\mathrm{X}}=3,85 \pm 0,54$; Keser ve Kocabaş (2014: 11 ) okul yöneticilerinde $\overline{\mathrm{X}}=3,90 \pm 0,37$; Erkmen ve Esen (2012: 62) bilişim sektörü çalışanlarında $\bar{X}=4,46 \pm 0,63$; Büyükgöze ve Kavak (2017: 13) lise ögretmenlerinde $\bar{X}=4,65 \pm 0,33$; Karadal ve Özsungur (2017: 670) sanayi çalışanlarında $\bar{X}=3,95 \pm 0,63$; Salha vd., (2016: 380) yiyecek ve içecek işletmeleri iş görenlerinde $\bar{X}=4,02 \pm 0,40$ olduğu gözlenmiştir. $\mathrm{Bu}$ çalışmada bulunan sonuç $(4,49 \pm 0,82)$ literatüre uygun ve sağ lık çalışanlarının psikolojik sermaye düzeylerinin oldukça yüksek seviyede olduğu ifade edilebilir.

\section{SONUÇ}

Günümüzde önemi artan konuların başında gelen psikolojik sermaye sadece sağlık sektöründe değil, çalışanlarının işlerinden tatmin olmalarını sağlayarak, verimliliklerini artırmak ve küresel rekabet ortamında büyümek isteyen tüm kurumların gündemlerinin başında gelmektedir. Bu çalışma insan hayatıyla bire bir ilişkili olan ve insan hayatına hizmet eden sağlık çalışanlarının psikolojik 
sermaye düzeylerini belirlemek ve psikolojik sermayenin iş tatmini ile olan ilişkisini ortaya koymak amacıyla yapılmıştır.

Katılımcıların psikolojik sermaye puan ortalaması literatür ile karşılaştırıldığında yüksek düzeyde olduğu ve bu konuda donanımlı oldukları ifade edilebilir. Belki de sağlık hizmetlerinin doğası gereği sağlık çalışanlarının kendilerini bu konuda hazırladıkları söylenebilir. Erkek katılımcıların psikolojik sermaye puan ortalaması kadın katılımcılara göre daha yüksek bulunmuştur. Katılımcıların yaşları yükseldikçe psikolojik sermaye puan ortalaması da yükselirken, genç yaştaki sağlık çalışanlarında psikolojik sermaye puan ortalaması daha düşük bulunmuştur. Bu sonuç ileri yaştaki çalışanların psikolojik sermaye düzeylerinin yüksek olduğunu göstermektedir. Bunun sebeplerinden birisi yıllar boyu edinilen tecrübeler olduğu söylenebilir.

Çalışmada katılımcıların demografik özelliklerinden cinsiyet, yaş, bulundukları kurumda çalışma süresi ve toplam mesleki yıl ile psikolojik sermaye düzeyleri arasında istatistiksel olarak anlamlı bir farklılık olduğu saptanmıştır. Katılımcıların toplam mesleki çalışma yıllarının artışıla psikolojik sermaye düzeyleri daha yüksek olduğu belirlenirken, çalışma yaşamlarının henüz başında olan sağlık çalışanlarında ise daha düşük düzeyde bulunmuştur. Bu çalışmada katılımcıların psikolojik sermaye ölçeği alt boyutlarıyla (umut, öz yeterlilik, iyimserlik, psikolojik dayanıklılık) iş tatmini arasında istatistiksel olarak pozitif yönlü anlamlı düzeyde bir ilişki olduğu tespit edilmiştir. Genel olarak değerlendirildiğinde sağlık çalışanlarının psikolojik sermaye düzeyleri ile iş tatmini arasında pozitif yönlü anlamlı düzeyde bir ilişki olduğu belirlenmiş ve araştırmada ifade edilen hipotezlerin tamamı doğrulanmıştır.

Literatürde psikolojik sermaye ile iş tatminini belirmeye yönelik farklı çalışmalarda psikolojik sermaye ile iş tatmini arasında pozitif yönlü anlamlı bir ilişki varlığı görülmektedir. Bu araştırmalarda bulunan korelasyon değerleri orta düzeyde iken, bu çalışmada bulunan korelasyon değerlerinin orta ve yüksek düzeyde olduğu ifade edilebilir. Bu sonuçlar bağlamında psikolojik sermayenin iş tatmininde önemli bir etken olduğu daha güçlü bir şekilde ortaya konmuştur denilebilir. Bu ilişki dikkate alındığında sağlık çalışanlarında psikolojik sermaye düzeyleri ile iş tatmini arasındaki ilişkiyi belirlemeye yönelik çalışmaların arttırılması ve kapsam bakımından genişletilmesi önerilebilir.

Pozitif psikolojik sermaye bir bütün olarak ve öz yeterlik, umut, iyimserlik ve dayanıklılık alt boyutlarıyla ölçülebilir ve eğitimlerle geliştirilebilir olması dikkate alındığında (Luthans vd., 2010:58), çalışanların iş tatmini artırmak amacıyla çalışanların psikolojik sermayelerini artırma yönünde eğitimler düzenlenebilir. $\mathrm{Bu}$ sadece iş tatmini için düşünülmemeli psikolojik sermaye ile aralarında doğru yönlü ilişki olan performans, örgütsel vatandaşlık, stresin 
üstesinden gelinmesi vb. gibi arzulanan ve olumlu çalışan davranışlarının artırılmasında ve psikolojik sermaye ile negatif yönlü ilişkisi gösterilen performans düşüklügü devamsızlık, işten ayrılma niyeti gibi istenmeyen çalışan davranışlarının da önüne geçilmesinde psikolojik sermayeden faydalanılması değerlendirilebilir. Hatta işe alımlarda psikolojik sermayesi yüksek adayların seçilmesine önem verilmesi bile düşünülebilir.

Her araştırmada olduğu gibi bu araştırmanın da kısıtları bulunmaktadır. Sağlık sektöründe hizmet veren bir kamu hastanesinde yapılan bu çalışmanın diğer kurumlara ve alanlara genellenememesi öncelikli bir kısıttır. Ayrıca sosyal bilimlerde yapılan ve anket yöntemini kullanan bütün araştırmalarda olduğu gibi katılımc1ların sorulara samimi ve dürüst cevap verdikleri ön kabulü ile yapılması da bu araştırmanın diğer bir kısıtıdır. Sektör itibariyle farklı iş kollarında psikolojik sermaye ile iş tatmini arasındaki ilişkileri belirlemeye yönelik çalışmalar yapılabileceği gibi sağlık sektöründe de konu kapsamlı olarak genişletilebilir. Bu araştırmada çalışanların psikolojik sermayelerin ölçümünde sadece kendilerinin değerlendirmeleri dikkate alınmıştır. Psikolojik sermayenin ölçümünde bireyin kendisi yanında aile fertleri, çalışma arkadaşları ve üstlerin de bireylerin psikolojik sermaye düzeylerini değerlendirebilecekleri araştırma modelleri kurgulanabilir. Özel sektör sağlık çalışanlarının örneklem olarak alındığı araştırmalar yapılabilir.

\section{KAYNAKLAR}

Akçay, Vildan Hilal (2012), "Pozitif Psikolojik Sermayenin İş Tatmini İle İlişkisi”, KSÜ İ̈BF Dergisi, 2(1), ss.123-140.

Akdemir, Bünyamin, Açan, Mesut Ahmet. (2017), "Psikolojik Sermaye ve İş Tatmini İlişkisini Belirlemeye Yönelik Bir Araştırma”, Akademik Yaklaşımlar Dergisi, 8(2), ss.57-79.

Akdoğan, Asuman ve Polatc1, Sema (2013), "Psikolojik Sermayenin Performans Üzerindeki Etkisinde İş Aile Yayılımı ve Psikolojik İyi Oluşun Etkisi”, Atatürk Üniversitesi Sosyal Bilimler Enstitüsü Dergisi, 17(1), ss.273-293.

Akman, Yener (2016), “Öğretmenlerin Psikolojik Sermaye Algılarının Çeşitli Değişkenlere Göre İncelenmesi”, Dicle Üniversitesi Ziya Gökalp Eğitim Fakültesi Dergisi, 28, ss.268-277.

Avey, James B. Luthans, Fred ve Jensen. Susan M. (2009), "Psychological Capital: A Positive Resource for Combating Employee Stress and Turnover”, Human Resource Management, 48(5), ss.677- 693. 
Avey, James B. Reichard, Rebecca, J. Luthans, Fred ve \& Mhatre, Ketan H. (2011), "Meta-Analysis Of The Impact Of Positive Psychological Capital On Employee Attitudes, Behaviours, and Performance", Human Resource Development Quarterly, 22(2), ss.127-152.

Avey, James B. Reichard, Rebecca, J. Luthans, Fred ve \& Mhatre, Ketan H. (2011b), "Meta-Analysis Of The Impact Of Positive Psychological Capital On Employee Attitudes, Behaviors, and Performance”, Human Resource Development Quarterly, 22, ss.127-52.

Badran, Mohga A. ve Youssef-Morgan, Carolyn M. (2015), "Psychological Capital and Job Satisfaction In Egypt", Journal of Managerial Psychology, 30(3), ss.354-370.

Basım, H.N. ve Şeşen, H. (2009), Örgütsel Adalet Algısı-Örgütsel Vatandaşlık Davranışı İlişsisinde İş Tatmininin Aracılık Rolü, 17’nci Yönetim ve Organizasyon Kongresi Bildiriler Kitabı, 21-23 Mayıs. Eskişehir.

Bergheim, Kjersti, Nielsen, Morten-Birkeland, Mearns, Kathryn ve Eid. Jarle (2014), "The Relationship Between Psychological Capital, Job Satisfaction, And Safety Perceptions In The Maritime Industry”, Safety Science, 74, ss.27-36.

Bowling, Nathan ve Cucina, Jeff (2015), "Robert Hoppock: Early Job Satisfaction and Vocational Guidance Pioneer", The IndustrialOrganizational Psychologist, 53, ss.109-116.

Büyükgöze, Hilal (2014), Lise öğretmenlerinin görüşlerine göre algılanan örgütsel destek ve psikolojik sermaye ilişkisi. Yayınlanmış yüksek lisans tezi. Hacettepe Üniversitesi Eğitim Bilimleri Enstitüsü. Ankara

Büyükgöze, Hilal ve Kavak, Yüksel (2017), “Algılanan Örgütsel Destek ve Pozitif Psikolojik Sermaye İlişkisi: Lise Öğretmenleri Örnekleminde Bir İnceleme”, Kuram ve Uygulamada Eğitim Yönetimi Dergisi (KUEY), 23(1), ss.1-32.

Cranny, C.L. Smith, P Ve Stone, F.F. (1992). Job Satisfaction: How People Feel About Their Job and How It Affects Their Performance, Lexingon Boks, New York.

Çetin, Fatih (2011), Örgütsel Vatandaşlık Davranışlarının Açıklanmasında Örgütsel Bağlılık, İş Tatmini, Kişilik ve Örgüt Kültürünün Rolü. Doktora tezi. Ankara: Ankara Üniversitesi Sosyal Bilimler Enstitüsü. 
Çetin, Fatih (2011), “The Effects of the Organizational Psychological Capital on the attitudes of Commitment and Satisfaction: A Public Sample in Turkey”, European Journal of Social Sciences, 21(3), ss.373-380.

Çetin, Fatih ve Basım, Nejat H. (2011), "Psikolojik Dayanıklılı̆ğın İş Tatmini ve Örgütsel Bağlılık Tutumlarındaki Rolü", "İŞ, GÜÇ” Endüstri İlişkileri ve İnsan Kaynakları Dergisi, 13(3), ss.79-94.

Çetin, Fatih ve Basım, Nejat H. (2012), “Örgütsel Psikolojik Sermaye: Bir Ölçek Uyarlama Çalışması”, Amme İdare Dergisi, 45(1), ss.121-137.

Erkmen, Turhan ve Esen, Emel (2012), “Bilişim Sektöründe Çalışanların Psikolojik Sermaye Düzeylerinin Belirlenmesine Yönelik Bir Araştırma”, Afyon Kocatepe Üniversitesi İktisadi ve İdari Bilimler Fakültesi Dergisi, 14(2), ss.55-72.

Erkmen, Turhan ve Esen, Emel (2013), “Psikolojik Sermaye Ölçeğinin Geçerlilik ve Güvenilirlik Çalışması”, Öneri Dergisi, 39(10), ss.23-30.

Erkuş, Ahmet ve Afacan Fındıklı, Mine (2013), "Psikolojik Sermayenin İş Tatmini, İş Performansı ve İşten Ayrılma Niyeti Üzerindeki Etkisine Yönelik Bir Araştırma”, Journal of The School of Business Administration, 42(2), ss.302-318.

Hackman, Richard ve Oldham, Greg R. (1975), "Development of the Job Diagnostic Survey”, Journal of applied psychology, 60(2), ss.159-170.

Hoppock, Robert (1935), Job Satisfaction, Harper, New York.

Kaplan, Metin ve Biçkes, Durdu Mehmet (2013), "The Relationship Between Psychological Capital And Job Satisfaction: A Study Of Hotel Businesses in Nevşehir”, Yönetim ve Ekonomi: Celal Bayar Üniversitesi İktisadi ve İdari Bilimler Fakültesi Dergisi, 20(2), ss.233-242.

Kara Uğurlu, Arzu (2014), Pozitif Psikolojik Sermaye İle Bireysel Performans İlişkisi: Tarım Kredi Kooperatifleri Merkez Birliği Örneği. Yayınlanmış Yüksek Lisans Tezi. Gazi Üniversitesi Sosyal Bilimler Enstitüsü. Ankara

Karadal, Himmet ve Özsungur, Fahri (2017), “Hizmet İnovasyon Davranışı İle Psikolojik Sermaye ve Etik Liderlik İlişkisinin İncelenmesi: Adana Örneği”, Uluslararası Yönetim İktisat ve İşletme Dergisi, Özel Sayısı, ss.663-672.

Karaman, Mesut, Macit, Mustafa ve Kuşcu Karatepe, Hilal (2020), "Psikolojik Sermayenin İş Performansına Etkisi: Sağlık Çalışanlarında Bir 
Uygulama”, Optimum Ekonomi ve Yönetim Bilimleri Dergisi, 7(1), ss.127-146.

Karatepe Kuşcu, Hilal, Kuşcu, Fatma Nuray ve Karaman, Mesut (2019), "Psikolojik Sermayenin Bireysel Performansa Etkisi: Hemşireler Üzerinde Bir Araştırma”, Anemon Muş Alparslan Üniversitesi Sosyal Bilimler Dergisi, 7(Eğitim ve Psikoloji Özel Sayısı), ss.105-114.

Keser, Sitar ve Kocabaş, İbrahim (2014), “illköğretim Okulu Yöneticilerinin Otantik Liderlik ve Psikolojik Sermaye Özelliklerinin Karşılaştırılması”, Kuram ve Uygulamada Eğitim Yönetimi, 1(1), ss.122.

Korkmazer, Fuat, Ekingen, Erhan ve Y1ldiz, Ahmet (2016), "Psikolojik Sermayenin Çalışan Performansına Etkisi: Sağlık Çalışanları Üzerinde Bir Araştırma”, Hacettepe Sağlık İdaresi Dergisi, 19(3), ss.271-281.

Kökalan, Özgür ve Şevik, Ümit (2017), “İş Tatmini İle Tükenmişlik Düzeyi Arasında Pozitif Psikolojik Sermayeni Aracı Etkisi”, Journal of Business Research Turk., 9(4), ss.713-733.

Kutanis, Rana Özen ve Oruç, Emre (2014), “Pozitif Örgütsel Davranış ve Pozitif Psikolojik Sermaye Üzerine Kavramsal Bir İnceleme”, The Journal of Happiness \& Well-Being, 2(2), ss.145-159.

Kwok, Sylvia Y.C.L. Cheng, Leveda ve Wong, Daniel F.K. (2015), "Family Emotional Support, Positive Psychological Capital and Job Satisfaction Among Chinese White-Collar Workers”, Journal of Happiness Stud., 16, ss.561-582.

Larson, Milan ve Luthans, Fred (2006), "Potential Added Value of Psychological Capital in Predicting Work Attitudes", Journal of Leadership and Organizational Studies, 13(1), ss.45-62.

Lawler, Edward III, ve Porter, Lyman (1967), “The Effect Of Performance On Job Satisfaction”, Industrial Relations, 7(1), ss.20-28.

Locke, Edwin (1969), “What Is Job Satisfactions?”, Organizational Behavior and Human Performance, 4(4), ss.309-336.

Locke, Edwin (1976). The Nature and Causes of Job Satisfaction, In M.D. Dunnette (Ed.), Handbook of industrial and organizational psychology. (ss. 1297-1343). Rand McNally, Chicago. 
Luthans, Fred (2002), Positive Organizational Behavior: Developing and Managing Psychological Strengths, Academy of Management Executive.

Luthans, Fred (2002), "The Need For And Meaning Of Positive Organizational Behavior”, Journal of Organizational Behavior. 23(6), ss.695-706.

Luthans, Fred ve Youssef, Carolyn M. (2007). "Emerging Positive Organizational Behavior”, Journal of Management, 33(3), ss.321-349.

Luthans, Fred, Avey, James B. Avolio, Bruce ve Peterson, Suzanne (2010), “The Development and Resulting Performance Impact of Positive Psychological Capital”, Human Resource Developmet Quarterly, 21(1), ss.41-67.

Luthans, Fred, Avolio, Bruce, Avey James, B. ve Norman Steven (2007), "Positive Psychological Capital: Measurement and Relationship With Performance and Satisfaction”, Personnel psychology, 60(3), ss.541572.

Luthans, Fred, Norman, Steven, Avolio, Bruce ve Avey, James B. (2008), “The Mediating Role Of Psychological Capital In The Supportive Organizational Climate-Employee Performance Relationship", Journal of Organizational Behavior, 29, ss.219-238.

Luthans, Fred, Youssef, Carolyn M. ve Avolio, Bruce (2006), Psychological Capital: Developing The Human Competitive Edge, Oxford University Press.

Luthans, Fred, Youssef, Carolyn M. ve Avolio, Bruce (2007a), Psychological capital: Developing the Human Competitive Edge, Oxford University Press NY.

Peterson, Christopher (2006), A primer in positive psychology, New York.

Peterson, Suzanne, Luthans, Fred, Avolio, Bruce, Walumbwa, Fred ve Zhang, Zhen (2011), "Psychological Capital and Employee Performance: A Latent Growth Modeling Approach”, Pers. Psychology, 64, ss.427-50.

Porter, Lyman, Steers, Richard, Mowday, Richard ve Boulian, Paul (1974), "Organizational Commitment, Job Satisfaction, and Turnover Among Psychiatric Technicians”, Journal of Applied Psychology, 59(5), ss.603609. 
Rego, Armenio, Marques, Carla, Leal, Susana, Sousa, Filipa ve Cunha Miguel (2010), "Psychological Capital And Performance Of Portuguese Civil Servants: Exploring Neutralizers In The Context Of An Appraisal System”, The International Journal of Human Resource Management, 21(9), ss.1531-1552.

Robbins, Stephen ve Judge, Timothy (2012), Örgütsel Davranış, (Çeviri Editörü: İnci Erdem), Nobel Yayıncılık, İstanbul.

Salha, Hamide, Cinnioğlu, Hasan ve Yazit, Hasibe (2016), Psikolojik Sermayenin İş Tatminine Etkisi: Tekirdağ'daki Yiyecek İçecek İşletmeleri Üzerine Bir Araştırma. 3rd International Congress Of Tourism \& Management Researches. 21, ss.371-385.

Seligman, Martin E. P. ve Csikszentmihalyi, Mihaly (2000), "Positive Psychology: An Introduction”, American Psychologist, 55, ss.5-14.

Spector, Paul (1997), Job Satisfaction: Application, Assessment, Causes, And Consequences, Thousand Oaks, Sage, California.

Stajkovic, Alexander D. ve Luthans, Fred (1998b), "Self-Efficay And Work Related Performance: A Meta-Analysis”, Physihological Bulltein, 124, ss.240-261.

Şen, Cem, Mert, İbrahim Sani ve Aydın, Oğuz (2017), “The Effects Of Positive Psychological Capital On Employee's Job Satisfaction, Organizational Commitment, And Ability Coping With Stress”, Journal of Academic Research In Economics, 9(2), ss.164-184.

Tabachnick Barbara ve Fidell, Linda S. (2013). Using Multivariate Statistics, (sixth ed.) Pearson, Boston.

Wright, Thomas A. (2003), "Positive Organizational Behavior: An İdea Whose Time Has Truly Come”, Journal of Organizational Behavior, 24(4), ss.437-442.

Yeşil, Salih; Yetiş, Emirhan ve Telli, Sümeyra (2016), "Psikolojik Sermaye ve Çalışanlar Üzerinde Etkisi: Banka Sektöründe Bir Alan Çalışması”, Internatonal Journal of Academic Value Studies, 2(2), ss.25-40.

Yıldız, Harun ve Örücü, Edip (2016), "Sağlık Sektörü Çalışanlarının Pozitif Psikolojik Sermaye Düzeylerinin Belirlenmesine Yönelik Bir Araştırma”, Yönetim ve Ekonomi Araştırmaları Dergisi, 14(1), ss.269285. 
Youssef, Carolyn M. ve Luthans. Fred (2007), "Positive Organizational Behavior in the Workplace: The Impact of Hope Optimism and Resilience”, Journal of Management, 33, ss.774-800.

Zağlı, Ali (2016), Psikolojik Sermayenin Çalışanın Stresle Başa Çıkma, İş Tatmini ve Örgütsel Bağlılığına Etkisi: Muğla Büyükşehir Belediyesi Örneği. Yüksek lisans tezi. Muğla S1tk1 Koçman Üniversitesi Sosyal Bilimler Enstitüsü, Muğla. 